\title{
PENGGUNAAN HAK ANGKET DEWAN PERWAKILAN RAKYAT REPUBLIK \\ INDONESIA, SETELAH PERUBAHAN UNDANG-UNDANG DASAR NEGARA REPUBLIK INDONESIA TAHUN 1945
}

\author{
David Aprizon Putra \\ Fakultas Syari'ah dan Ekonomi Islam IAIN Curup \\ Email : davidaprizonputra@gmail.com
}

\begin{abstract}
Dewan Perwakilan Rakyat Republik Indonesia is one of the institutions of the state that has experienced the impact of the change. One line that significantly changes is on the function line. After the changes in the Undang-Undang Dasar 1945 the Dewan Perwakilan Rakyat Republik Indonesia has three functions in which the matter is mandated in article 20A (1). The three functions are legislative functions, budget functions and supervisory functions. One of the functions of supervision owned by the Dewan Perwakilan Rakyat Republik Indonesia is the inquiry right. Prior to the changes in the Second State ndang-Undang Dasar 1945, the oversight function of the Dewan Perwakilan Rakyat Republik Indonesia was only regulated in a general explanation, and this also seems very general and has not been explicitly explained. Then after the second amendment to the ndang-Undang Dasar 1945, then the inquiry right as one of the supervisory functions was more explicitly regulated, namely in Article 20A (2). The legal consequences of the use of the ndang-Undang Dasar 1945 inquiry rights to the President's policies can lead to efforts to dismiss the president and, or Vice-President, if the president's policy violates article 7A of the Undang-Undang Dasar 1945, from that the author considers this need to be understood and studied more deeply.
\end{abstract}

Keywords: Constitution; Questionnaire Rights; Amendement

\begin{abstract}
ABSTRAK
Dewan Perwakilan Rakyat Re[ublik Indonesia merupakan salah satu lembaga Negara yang mengalami dampak perubahan itu. Salah satu lini yang secara signifikan mengalami perubahan adalah pada lini fungsi. Pasca perubahan Undang-Undang Dasar Negara Republik Indonesia Tahun 1945 Dewan Perwakilan Rakyat mempunyai tiga fungsi dimana perihal tersebut diamanatkan dalam pasal 20A (1). Ketiga fungsi tersebut adalah fungsi legislasi, fungsi anggaran dan fungsi pengawasan. Salah satu fungsi pengawasan yang dimiliki oleh Dewan Perwakilan Rakyat adalah Hak angket. Sebelum adanya perubahan kedua UndangUndang Dasar Negara Republik Indonesia Tahun 1945, fungsi pengawasan Dewan Perwakilan Rakyat hanya diatur dalam penjelasan umum, dan hal ini-pun masih terlihat sangat umum dan belum secara eksplisit dijelaskan. Kemudian pasca perubahan kedua Undang-Undang Dasar Negara Republik Indonesia Tahun 1945, kemudian hak angket sebagai salah satu fungsi pengawasan ini diatur lebih tegas yaitu dalam Pasal 20A (2). Akibat hukum dari penggunaan hak angket Dewan Perwakilan Rakyat ini terhadap kebijakan Presiden dapat mengarah kepada upaya pemberhentian presiden dan,atau Wakil Presiden, jika kebijakan presiden tersebut melanggar pasal 7A Undang-Undang Dasar Negara Republik Indonesia Tahun 1945. Hal ini mungkin saja bisa terjadi, maka dari itu penulis menganggap hal ini perlu untuk dipahami dan dikaji lebih dalam.
\end{abstract}

Kata kunci : Konstitusi; Hak angket; Amandemen 


\section{Pendahuluan}

Secara umum fungsi Dewan Perwakilan Rakyat, selanjutnya disebut DPR terdiri fungsi legislasi, fungsi anggaran dan fungsi pengawasan. Dari ketiga fungsi tersebut, fungsi legislasi dianggap fungsi utama dari DPR. Lembaga Legislatif adalah kekuasaan pemerintah yang mengurusi pembuatan hukum, sejauh hukum tersebut memerlukan kekuatan undang-undang (statutory force). ${ }^{1}$ Spesialisasi fungsi tersebut tentunya akan bersesuaian dengan konteks teori pemisahan kekuasaan, yang memisahkan kekuasaan legislatif, eksekutif dan yudikatif sesuai spesialisasi masingmasing. Sebagaimana dituliskan oleh Montesquieu $^{2}$ yang disadur dalam sebuah buku yang berjudul Asas Negara Hukum, Peraturan Kebijakan dan Asas-Asas umum Pemerintahan yang Baik ${ }^{3}$ :

"Again there is no liberty, if the judiciary power be not separated from legislative and executive. Were it joined with the legislative, the life and liberty of the subject would be exposed to arbitraty control, for the judge would then be legislator. Were it joined

${ }^{1}$ C.F Strong, Konstitusi-Konstitusi Politik-Politik Modern, Studi Perbandingan Sejarah dan Bentuk,Nusa Media, 2013, hlm.11

${ }^{2}$ Adalah pemikir politik Perancis yang hidup pada Era Pencerahan (Enlightenment). Ia terkenal dengan teorinya mengenai pemisahan kekuasaan yang banyak disadur pada diskusi-diskusi mengenai pemerintahan dan diterapkan pada banyak konstitusi di seluruh dunia. Ia memegang peranan penting dalam memopulerkan istilah "feodalisme" dan "Kekaisaran Bizantium"

${ }^{3}$ Hotma P Sibuea, Asas Negara Hukum, Peraturan Kebijakan dan Asas-Asas umum Pemerintahan yang Baik, Erlangga, 2010, hlm. 25 with the executive power, the judge might behave with violence and oppression.

(Tidak ada kebebasan jika kekuasaan yudisial tidak dipisahkan dari kekuasaan legislatif dan eksekutif. Jika kekuasaan yudisial bersatu dengan kekuasaan legislatif kehidupan dan kebebasan Warga Negara akan diperhadapkan pada pengawasan yang sewenang-wenang karena hakim menjadi pembentuk undang-undang. Jika kekuasaan yudisial bersatu dengan kekuasaan eksekutif, hakim akan berperilaku jahat dan kejam)."

Namun seiring perkembangannya, kekuasaan DPR mulai melebar dan masuk kedalam ranah pengawasan terhadap eksekutif. Apabila kita lihat dari fakta ini, maka secara otomatis bahwa telah terjadi pergeseran makna terhadap konsep pemisahan kekuasaan. Sebagaimana kita ketahui, hakikat dari teori pemisahan kekuasaan adalah agar tidak terjadi sentralisasi kekuasaan yang hanya bertumpu pada satu lembaga kekuasan saja. Dibutuhkan deskripsi pemisahan kekuasaan yang jelas baik pada tataran regulasi yang menetapkannya ataupun pada pelaksanannya. Maka secara fungsional, job description-nya harus jelas dan dipisah-pisah sesuai dengan peruntukannya. Sehingga tidak ada upaya saling intervensi antar lembaga yang satu dengan yang lainnya.

Undang-Undang Dasar berfungsi sebagai "pola umum" penyelengaraan Negara, yang berisi aturan-aturan terpokok sebagai "rule of the game" dalam 
menyelenggarakan suatu pemerintahan Negara. ${ }^{4}$ Kekuatan baru yang dimiliki Undang-Undang Dasar Negara Republik Indonesia Tahun 1945 ini menjadikan DPR semakin kuat dan berjalan dengan pasti menuju kepada kondisi legislative heavy. Ketentuan pasal 20A (2) Undang-Undang Dasar Negara Republik Indonesia Tahun 1945, selanjutnya disebut UUD 1945 yang mengakomodir secara tegas fungsi pengawasan DPR terhadap lembaga eksekutif, maka jelaslah bahwa akan ada kemungkinan intervensi DPR terhadap eksekutif.

Dibalik semua fakta empiris diatas, maka sebenarnya ada alasan kuat mengapa UUD 1945 mengakomodir hal tersebut. Fakta sejarahlah yang berbicara, mengambil hikmah dari sejarah masa lalu maka untuk saat ini sangatlah benar apabila dilakukan tindakan seperti itu. Kita meiliki sejarah kelam dan kurang sedap dipandang pada masa lalu, kekuasaan eksekutif pada masa itu merajalela, sehingga terjadi lah eksekutive heavy. Presiden dengan kekuasaan absolut serta baju hukum rapi yang dimilikinya, memiliki super power yang tak terbendung, kekuatan legislatif muncul hanya sebagai formalitas. Pergeseran kewenangan membentuk undang-undang dari sebelumnya ditangan presiden dan dialihkan kepada DPR

\footnotetext{
${ }^{4}$ Rosjidi Ranggawidjaja, Undang-Undang Dasar 1945 : diubah atau diganti ?, Universitas Padajdjaran, 2012, hlm. 14.
}

merupakan langkah kostitusional untuk meletakkan secara tepat fungsi-fungsi lembaga negara sesuai bidang tugasnya masing-masing yakni DPR sebagai lembaga pembentukan undang-undang (kekuasaan legislatif) dan Presiden sebagai lembaga pelaksana undang-undang (kekuasaan eksekutif). ${ }^{5}$ Sebagaimana hal ini sesuai dengan pernyataan Lord Acton bahwa Power tends to corrupt, absolute power tends to corrupt absolutely (manusia yang memiliki kekuasaan akan cenderung untuk menyalahgunakannya, akan tetapi manusia yang mempunyai kekuasaan absolut sudah pasti akan menyalahgunakannya). ${ }^{6}$

Dari aspek kekuasaan, maka pemerintah akan memiliki kecerendungan menyimpang yang lebih besar dari pada lembaga lain. Apabila kita kembalikan adegium hukum diatas kepada kondisi Negara kita, yang notabene merupakan Negara yang sedang dalam tahap berkembang dan berkonsep Negara kesejahteraan, maka sengat jelas bahwa sistem penguasaan kekuasaan oleh pemerintah adalah bersifat diskresi. Hal ini menjadi wajib dalam penentuannya, dan pemerintah kita telah pernah mengkhianati kondisi tersebut. Dari kesemua penjelasan diatas maka sangatlah jelas, bahwasanya

\footnotetext{
5 Ni'matul Huda, Hukum Tata Negara Indonesia,PT Raja Grafindo Persada, 2012, hlm.177

6 Miriam Budiarjo, Dasar-Dasar Ilmu Politik, PT Gramedia Pustaka Utama, Cetakan ke-16, 1995, hlm. 9
} 
terdapat alasan kuat sehingga mengapa diperlukan perubahan UUD 1945 menyangkut sistem pemisahan kekuasaan lembaga Negara.

Di Indonesia fungsi legislasi masih menjadi fokus urutan pertama dalam pelaksanaan sistem hukum di Indonesia. Berbeda halnya dengan Negara-negara lain, terutama Negara yang notabene merupakan Negara yang sudah maju. Mereka sudah tidak menitikberatkan masalah legislasi, melainkan mereka sudah lebih fokus kepada fungsi pengawasan. Hal ini disebabkan karena mereka sudah dianggap memiliki pedoman hukum yang bagus dan sesuai untuk Negara mereka saat ini, sehingga mereka sudah maju satu langkah dari kita, dan sekarang hanya sibuk mengurusi masalah fungsi pengawsan saja lagi. Sebagaimana disebutkan oleh Jimly Asshidiqie $^{7}$, diseluruh penjuru dunia lebih diutamakan adalah fungsi pengawasan daripada fungsi legislasi.

Masih menurut Jimly Asshidiqie, ${ }^{8}$ secara teoritis fungsi-fungsi kontrol atau pengawasan oleh parlemen atau lembaga Perwakilan Rakyat dapat pula dibedakan ; 1.Pengawasan terhadap penentuan kebijakan (control of policy making); 2.Pengawasan terhadap pelaksanaan kebijakan (control of policy executing); 3.Pengawasan terhadap penganggaran dana Negara (control of

\footnotetext{
7 Jimly Asshidiqie, Pengantar Ilmu Hukum Tata Negara Jilid II, Penerbit Konstitusi Pers, 2012, hlm. 34

${ }^{8}$ Ibid, hlm. 36
}

budget implementation); 4.Pengawasan terhadap kinerja pemerintahan (control of government control); 5.Pengawsan terhadap pengangkatan pejabat publik (control of political appointment of public officials) dalam bentuk persetujuan atau penolakan, ataupun dalam bentuk pemberian pertimbangan oleh DPR.

Secara konstitusional fungsi pengawasan DPR dibagi menjadi dua, yang pertama adalah fungsi pengawasan DPR secara kelembagaan dan yang kedua fungsi pengawasan DPR secara perorangan (anggota DPR). Fungsi pengawasan DPR secara kelembagaan adalah hak interpelasi, hak angket dan hak menyatakan pendapat. Sedangkan fungsi pengawasan DPR secara perorangan adalah hak mengajukan pertanyaan. Dimana penjelasan diatas ada dalam pasal 20A UUD 1945.

Berdasarkan pasal 77 (1) (2) dan (3) Undang-Undnag Nomor 27 tahun 2009 tentang Majelis Permusyawaratan Rakyat, Dewan Perwakilan rakyat, Dewan Perwakilan Daerah, hak interpelasi adalah hak DPR untuk meminta keterangan kepada pemerintah mengenai kebijakan pemerintah yang penting dan strategis dan berdampak luas pada kehidupan bermasyarakat, berbangsa dan bernegara. Hak angket adalah hak DPR untuk melakukan penyelidikan terhadap pelaksanaan suatu undang-undang dan/atau kebijakan pemerintah yang berkaitan dengan hal penting,strategis dan 
berdampak luas pada kehidupan bermasyarakat, berbangsa dan bernegara yang diduga bertentangan dengan peraturan perundang-undangan. Hak menyatakan pendapat adalah hak DPR untuk menyatakan pendapat atas; a. kebijakan pemerintah atau mengenai kejadian luar biasa yang terjadi di tanah air atau didunia internasional; b. tindak lanjut pelaksanaan hak interpelasi dan hak angket; c. dugaan bahwa Presiden dan/atau Wakil Presiden melakukan pelanggaran hukum berupa pengkhianatan terhadap Negara, korupsi, penyuapan, tindak pidana berat lainnya, maupun perbuatan tercela dan/atau Presiden dan/atau Wakil Presiden tidak lagi memenuhi syarat sebagai Presiden dan/atau Wakil Presiden.

Dapat disimpulkan dari ketetapan diatas bahwa fungsi pengawasan DPR mengenai hak interpelasi, hak angket dan hak menyatakan pendapat merupakan fungsi pengawasan DPR terhadap pelaksaan kebijakan yang dilakukan oleh Pemerintah. Hak Angket disebut juga sebagai hak penyelidikan, karena hak ini memang dimiliki oleh DPR untuk menyelidiki sesuatu yang lazimnya terkait dengan hal-hal yang terkait dengan masalah keuangan yang menjadi kebijakan Pemerintah. Namun ketentuan Pasal 176 ayat (1) Peraturan Tata Tertib DPR menegaskan bahwa hak angket digunakan untuk menyelidiki "kebijakan pemerintah yang penting dan strategis serta berdampak luas pada kehidupan bermasyarakat dan bernegara yang diduga bertentangan dengan peraturan perundangundangan". Rumusan ini memang sangat luas, karena setiap gerak langkah dan keputusan yang diambil Pemerintah pada dasarnya dapat dikatakan sebagai "kebijakan". Jadi tidak spesifik terkait dengan masalah keuangan negara sebagaimana pemahaman teoritis tentang asal muasal hak angket.

Fungsi pengawasan yang menurut penulis sangat menarik untuk dikaji adalah fungsi pengawasan DPR terkait masalah hak angket. Sepanjang perjalanan pemerintahan Orde Baru, penggunaan hak angket DPR terhadap Pemerintah tidak pernah dilakukan. DPR secara empirik hanya berfungsi secara formalitas saja, seperti halnya penulis singgung pada bagian awal tulisan ini. DPR hanya manjadi aktor figuran dalam menjalankan roda pemerintahan, dimana Pemerintah-lah yang menjadi sutradara sekaligus aktor utama (pemeran utama). Terjadi eksecutive heavy pada masa itu, pembagian kekuasaan yang tidak berimbang yang mengakibatkan chek and balanches system tidak berjalan, bahkan tidak ada.

Secara faktual, dalam praktek ketatanegaraan pasca perubahan UUD 1945, DPR sudah beberapa kali menggunakan hak angketnya. Hal yang menjadi muara dari permasalahan hak angket ini adalah pada poin akibat hukumnya, bagaimana akibat hukum penggunaan hak angket DPR 
terhadap kebijakan pemerintah. Jadi penulis akan mambahas dua pokok permasalah yang menjadi pertanyaan paling urgen menyangkut penggunaan hak angkat oelh DPR terhadap pelaksaan kebijakan yang dilakukan oleh Pemerintah. Pertama, Apakah posisi hak angket pada masa pra perubahan UUD 1945 bisa digunakan DPR untuk mengarahkan pada upaya pemberhentian Presiden dan/atau Wakil presiden (impiechment)? Kedua, Apakah posisi hak angket pada masa pasca perubahan UUD 1945 bisa digunakan DPR untuk mengarahkan pada upaya pemberhentian Presiden dan/atau Wakil presiden (impiechment)?

\section{Hasil dan Pembahasan}

\section{Hak Angket DPR sebelum Perubahan UUD 1945}

Sebagaimana penulis sebutkan pada bagian awal, bahwa pada masa ini UUD 1945 tidak menyebutkan secara ekplisit dalam batang tubuhnya, mengenai pengaturan fungsi pengawasan DPR, terlebih pengaturan mengenai hak angket. Hak angket DPR bahkan tidak disebut secara eksplisit dalam penjelasan umum UUD 1945 sebagai bagian dari fungsi pengawasan DPR. Dalah penjelasan umum tersebut hanya menjelaskan bahwa :

"Kedudukan Dewan Perwakilan Rakyat adalah kuat. Dewan ini tidak bisa dibubarkan oleh Presiden (berlainan dengan sistem parlementer).
Kecuali ini anggota-anggota Dewan Perwakilan Rakyat semuanya merangkap menjadi anggota Majelis Permusyawaratan Rakyat. Oleh karena itu, Dewan Perwakilan Rakyat dapat senantiasa mengawasi tindakantindakan Presiden dan jika Dewan menganggap bahwa Presiden sungguh melanggar Haluan Negara yang telah ditetapkan oleh Undang-Undang Dasar atau Majelis Permusyawaratan Rakyat, maka Majelis itu dapat diundang untuk persidangan istimewa agar supaya bisa minta pertanggungan jawab kepada Presiden". 9

Apabila kita kaji dari rumusan penjelasan umum UUD 1945 sebagaimana disebutkan diatas, maka dapat disimpulkan bahwa rumusan tentang wewenang mengawasi yang dilakukan oleh DPR terkait pelaksanaan Haluan Negara oleh Presiden adalah hak interpelasi, sebab pelaksanaan haluan Negara itu berkaitan dengan pertanggung jawaban politik Presiden.

Penggunaan hak angket pada masa ini (Orde Baru/belum dirubahnya UUD 1945) secara yuridis konstitusional tidak bisa diarahkan pada upaya pemberhentian Presiden dan/atau Wakil Presiden (impiechment). Jelas didalam UUD 1945 pada masa ini, tidak ada ketentuan hukum yang mengatur ini, sehingga upaya tersebut memang tidak akan pernah bisa dilakukan. Pada masa ini upaya yang dilakukan terkait upaya pengawasan terhadap Presiden dan/atau Wakil Presiden adalah hanya dengan menyerahkan hasil penyelidikannya

\footnotetext{
${ }^{9}$ Penjelasan Umum UUD 1945
} 
kepada aparat penegak hukum agar ditindak lanjuti. Jadi dapat disimpulkan pada masa ini, Indonesia belum memiliki peristilahan hak angket dimana yang dimaksud pada pengertiannya dewasa ini.

Satu contoh kasus yang menarik terkait dengan permasalahan impeachment adalah pada kasus mantan Presiden Gus Dur. Kasus ini terjadi dan ditetapkan keabsahannya pada bulan juli sebelum penetapan perubahan ketiga UUD 1945, yang ditetapkan dan disahkan pada bulan nopember. Sebagimana kita ketahui Gus Dur diberhentikan akibat dugaan melakukan skandal korupsi Bulog dan Brunei, dimana kemudian pada masa itu kita mengenal peristilahan Bulogate dan Bruneigate. Prosedur yang digunakan dalam rangka untuk menggiring Gus Dur pada pintu pemakzulan ini bukan merupakan mekanisme hak angket melainkan merupakan rangkaian mekanisme interpelasi. Pada waktu proses hak angket DPR berjalan pada waktu itu, DPR memberikan memorandum I dan II kepada Gus Dur. Berdasarkan TAP MPR No.III/MPR/1978 dinyatakan bahwa apabila dianggap sungguh melanggar Haluan Negara, maka DPR menyampaikan memorandum untuk mengingatkan Presiden. Apabila dalam waktu tiga bulan Presiden tidak memperhatikan memorandum DPR tersebut, maka DPR akan melakukan memorandum kedua. Apabila dalam waktu satu bulan memorandum yang kedua tersebut tidak diindahkan oleh Presiden maka DPR dapat meminta majelis mengadakan sidang istimewa untuk meminta pertanggung jawaban Presiden.

Tindakan MPR yang menjadikan kasus Bulog dan Brunei sebagai dasar untuk memberhentikan gusdur dari jabatannya sebagi Presiden, maka dapat kita maknai bahwa MPR pada masa ini memiliki kekuasaan yang tak terbatas, hal ini dijelaskan pada penjelasan pasal 3 UUD 1945 yang menyatakan bahwa “ Oleh karena MPR memegang kedaulatan negara maka kekuasaannya tidak terbatas .........'.

\section{Penggunaan Hak Angket DPR Setelah Perubahan UUD 1945}

Perubahan UUD 1945 akan selalu berimplikasi pula pada perubahan sistem ketatanegaraan, terutama terkait pada hubungan antar lembaga negara. Perubahan yang nyata tentang hubungan antar lembaga negara adalah berkaitan dengan struktur lembaga negara Indonesia pasca perubahan UUD 1945. Sebagaimana diketahui struktur sebelum perubahan UUD 1945 secara garis besar dibagi menjadi dua, yakni lembaga tertinggi negara (MPR) dan lembaga tinggi negara, seperti Presiden, DPR, MA dan BPK. Keberadaan MPR sebagai lembaga tertinggi sebelum perubahan UUD 1945, ternyata menimbulkan problem ketatanegaraan yang cukup serius, terutama terkait masalah hubungannya dengan lembaga-lembaga tinggi negara pada masa itu, seperti Presiden. Apalagi secara 
komposisi anggopta MPR adalah anggota DPR.

Dalam praktek ketatanegaraan dimanapun, hubungan kelembagaan yang paling dekat adalah antara DPR dan Presiden. Karena hubungan antara kedua lembaga negara ini memiliki keterkaitan yang sangat kuat. DPR mempunyai kewenangan dalam mengawasi kebijakan dan kinerja Presiden. Terkait dengan implikasi fungsi pengawasan DPR semisal hak angket yang memungkinkan terjadinya ketegangan antara kedua belah pihak, maka ini akan jelas menganggu roda pemerintahan. Maka dari itu, bahwa sejatinya masalah fungsi pengawasan DPR ini menjadi sangat penting dalam pengkajiannya, upaya terbaik yang dilakukan adalah tentunya dengan membenahi sistem ketatanegraan yang berkaitan dengan hubungan yang mengatur antar lembaga-lembaga negara itu sendiri.

Apabila kita mengkaji masalah hubungan antara DPR dan Presiden maka mau tidak mau kita harus kembali mengkaji tentang sistem pemerintahan. Secara umum kita mengenal bahwa sistem pemerintahan di dunia ini ada dua, yaitu sistem Presidensil dan Parlementer. Sebagimana pula dituliskan oleh Prof. Mahfud MD didalam bukunya yang berjudul Dasar dan Struktur Ketatanegaraan Indonesia $:{ }^{10}$ Ciri-ciri sistem Presidensil : (1) Kepala Negara

\footnotetext{
${ }^{10}$ Mahfud MD, Dasar dan Struktur Ketatanegaraan Indonesia. Rineka Cipta, 2000, hlm. 74-75
}

menjadi Kepala Pemerintahan (eksekutif); (2) Pemerintahan tidak bertanggung jawab kepada Parlemen (DPR), Pemerintahan dan Parlemen adalah sejajar; (3) Menteri-menteri diangkat dan bertanggung jawab kepada Presiden; (4) Eksekutif dan legislatif samasama kuat. Adapun Ciri-ciri sistem Parlementer sebagai berikut : (1) Kepala Negara tidak berkedudukan sebagai Kepala Pemerintahan karena ia lebih bersifat Simbol Nasional (pemersatu bangsa); Pemeriintah dilakukan oleh sebuah kabinet yang dipimpin oleh Perdana Menteri; (3) Kabinet bertanggung jawab kepada Parlemen dan dapat dijatuhkan oleh Parlemen melalui mosi; (4) Kedudukan eksekutif (Kabinet) lebih rendah dan tergantung pada Parlemen. Sebagai imbangan dan lemahnya Kabinet ini, maka Kabinet dapat meminta Kepala Negara untuk membubarkan Parlemen (DPR) dengan alasan yang sangat kuat sehingga Parlemen dinilai tidak representatif.

Dari penjelasan tersebut, secara teoritik maka sangatlah jelas mengenai kedua sistem pemerintahan yang ada di dunia ini. Apabila kita kembalikan pada konteks Indonesia, maka dapat disimpulkan kita tidak jelas (kabur) dalam menentukan kiblat sistem pemerintahan. Kalo kita analogikan kepada kelamin, maka jenis kelamin kita tidak jelas, karena kita stengah-setengah dalam menerapkan sitem itu. Kita lakukan yang ditentukan Presidensil dan kita lakukan pula ketentuan yang ada pada parlementer. Dari 
sini saja kita sudah dapat melihat, bahwa kita sekarang berada dalam masalah.

Terkait pada relasi antara Presiden dan DPR, meskipun dalam UUD 1945 dijelaskan bahwa kedudukan DPR dan Presiden samasama kuat, tetapi model pertanggung jawaban Presiden terhadap MPR itu merupakan ciri dari Parlementer. Dengan tidak adanya ketegasan dalam sistem pemerintahan dalam UUD 1945 maka akan secara jelas pula akan berakibat kepada ketidakjelasan hubungan antar lembaga negara, terutama DPR dan Presiden.

Kesepakatan panitia Ad Hoc I MPR pada masa itu, satu agenda yang dibahas adalah mengenai pemilihan sistem pemerintahan Indonesia, dimana hasilnya adalah tetap memilih sistem Presidensil dan memperkuat statusnya. Alasan yang menjadi ketetapan tersebut karena, sistem Presidensil adalah karena upaya penstabilan roda pemerintahan akan berjalan lebih muda. Gejolak-gejolak yang muncul berkaitan dengan upaya impeachment akan lebih mudah terkontrol, kecuali apabila karena sebab-sebab yang memang telah ditentukan sebagimana halnya yang telah terjadi pada UUD 1945 sekarang ini. Bila ditafisrkan, secara harfiah dalam kedua pasal ini (Pasal 7A dan 7B UUD 1945) :

Pasal 7A menyatakan bahwa : Presiden dan/atau Wakil Presiden dapat diberhentikan dalam masa jabatannya oleh Majelis Permusyawaratan Rakyat atas usul
Dewan Perwakilan Rakyat, baik apabila terbukti telah melakukan pelanggaran hukum berupa pengkhianatan terhadap negara, korupsi, penyuapan, tindak pidana berat lainnya, atau perbuatan tercela maupun apabila terbukti tidak lagi memenuhi syarat sebagai Presiden dan/atau Wakil Presiden.

Sebelum perubahan, Undang-Undang Dasar Negara Republik Indonesia Tahun 1945 belum memuat ketentuan yang mengatur pemberhentian Presiden dan/atau Wakil Presiden dalam masa jabatannya. Undang-Undang Dasar Negara Republik Indonesia Tahun 1945 hanya mengatur hal itu di dalam Penjelasan Undang-Undang Dasar Negara Republik Indonesia Tahun 1945 bahwa DPR mengusulkan sidang istimewa MPR dan MPR meminta pertanggungjawaban Presiden. Hal itu di samping bertentangan dengan sistem presidensial juga membuka peluang terjadinya ketegangan dan krisis politik dan kenegaraan selama masa jabatan Presiden dan/atau Wakil Presiden, seperti yang kerap kali terjadi dalam praktik ketatanegaraan kita. Praktik ketatanegaraan seperti itu lebih merupakan pelaksanaan sebuah sistem pemerintahan parlementer yang tidak dianut negara kita. Untuk itu, perubahan UndangUndang Dasar Negara Republik Indonesia Tahun 1945 memuat ketentuan pemberhentian Presiden dan/atau Wakil Presiden dalam masa jabatannya (impeachment) yang didasarkan pada alasan 
hukum ataupun alasan lain, yang tidak bersifat politik dan multitafsir seperti yang terjadi pada era sebelumnya. Dengan adanya rumusan Undang-Undang Dasar Negara Republik Indonesia Tahun 1945 yang secara tegas dan jelas mengatur mengenai impeachment, hanya atas alasan yang tercantum dalam ketentuan Pasal 7A saja, seorang Presiden dan/atau Wakil Presiden dapat diberhentikan dalam masa jabatannya. Itu pun hanya dapat dilakukan setelah melalui proses konstitusional melalui Mahkamah Konstitusi (MK) dan DPR.

Peran MK menegaskan bekerjanya prinsip negara hukum. Putusan MK merupakan putusan hukum yang didasarkan pada pertimbangan hukum semata. Posisi putusan MK menjadi rujukan/acuan bagi DPR mengenai apakah usul pemberhentian Presiden dan/atau Wakil Presiden tersebut diteruskan atau dihentikan.

Prosedur pemberhentian Presiden dan/atau Wakil Presiden dalam masa jabatannya sebagaimana ketentuan Pasal 7A diatur dalam ketentuan Pasal 7B yang terdiri atas tujuh ayat, yaitu ayat (1), ayat (2), ayat (3), ayat (4), ayat (5), ayat (6), dan ayat (7) dengan rumusan sebagai berikut. Pasal 7B menyatakan bahwa :

(1) Usul pemberhentian Presiden dan/atau Wakil Presiden dapat diajukan oleh Dewan Perwakilan Rakyat kepada Majelis Permusyawaratan Rakyat hanya dengan terlebih dahulu mengajukan permintaan kepada
Mahkamah Konstitusi untuk memeriksa, mengadili, dan memutus pendapat Dewan Perwakilan Rakyat bahwa Presiden dan/atau Wakil Presiden telah melakukan pelanggaran hukum berupa pengkhianatan terhadap negara, korupsi, penyuapan, tindak pidana berat lainnya, atau perbuatan tercela; dan/atau pendapat bahwa Presiden dan/atau Wakil Presiden tidak lagi memenuhi syarat sebagai Presiden dan/atau Wakil Presiden.

Ketentuan tersebut dilatarbelakangi oleh kehendak untuk melaksanakan prinsip saling mengawasi dan saling mengimbangi antarlembaga negara (DPR, Presiden, dan MK) serta paham mengenai negara hukum. Sesuai dengan bidang kekuasaannya, sebagai lembaga perwakilan, DPR mengusulkan pemberhentian Presiden dan/atau Wakil Presiden dalam masa jabatannya. Usul pemberhentian itu merupakan pelaksanaan fungsi pengawasan yang dimiliki oleh DPR. MK menjalankan proses hukum tersebut atas usul pemberhentian tersebut dengan cara memeriksa, mengadili, dan memutus pendapat DPR.

(2) Pendapat Dewan Perwakilan Rakyat bahwa Presiden dan/atau Wakil Presiden telah melakukan pelanggaran hukum tersebut ataupun telah tidak lagi memenuhi syarat sebagai Presiden dan/atau Wakil Presiden adalah dalam rangka pelaksanaan fungsi pengawasan Dewan Perwakilan Rakyat. 
Ketentuan tersebut dilatarbelakangi oleh sistem ketatanegaraan kita yang menempatkan DPR dan Presiden dalam kedudukan yang setara/seimbang. Oleh karena itu, Undang-Undang Dasar Negara Republik Indonesia Tahun 1945 menetapkan bahwa Presiden tidak dapat membubarkan DPR dan DPR tidak dapat menjatuhkan Presiden. Sehubungan dengan hal tersebut, salah satu fungsi DPR adalah fungsi pengawasan terhadap Presiden (dan Wakil Presiden serta pemerintah secara umum). Dalam pelaksanaan fungsi pengawasan tersebut, DPR dapat berpendapat bahwa Presiden dan/atau Wakil Presiden diduga telah melakukan pelanggaran hukum, atau perbuatan tercela, dan/atau tidak lagi memenuhi syarat sebagai Presiden dan/atau Wakil Presiden. Atas pendapatnya tersebut, DPR dapat mengajukan usul pemberhentian Presiden dan/atau Wakil Presiden kepada MPR sebagai lembaga negara yang berwenang memberhentikan Presiden dan/atau Wakil Presiden dalam masa jabatannya sesuai dengan keten-tuan Pasal 3 ayat (3) Undang-Undang Dasar Negara Republik Indonesia Tahun 1945. Karena kedudukan DPR sejajar/seimbang dengan kedudukan Presiden sehingga keduanya tidak dapat saling menjatuhkan, DPR tidak memproses dan tidak mengambil putusan terhadap pendapatnya sendiri. Oleh karena itu, DPR mengajukannya kepada MK untuk memeriksa, mengadili, dan memutus pendapat yang berisi dugaan DPR itu. Jika putusan MK menyatakan Presiden dan/atau Wakil Presiden terbukti melakukan pelanggaran hukum, atau perbuatan tercela, dan/atau terbukti tidak lagi memenuhi syarat sebagai Presiden dan/atau Wakil Presiden, DPR meneruskan usul pemberhentian ke MPR. Ketentuan itu juga merupakan salah satu pelaksanaan prinsip saling mengawasi dan saling mengimbangi antarlembaga negara, khususnya antara DPR, MK, dan MPR sesuai dengan kedudukan dan wewenangnya yang berbeda.

(3) Pengajuan permintaan Dewan Perwakilan Rakyat kepada Mahkamah Konstitusi hanya dapat dilakukan dengan dukungan sekurang-kurangnya 2/3 dari jumlah anggota Dewan Perwakilan Rakyat yang hadir dalam sidang paripurna yang dihadiri oleh sekurang-kurangnya $2 / 3$ dari jumlah anggota Dewan Perwakilan Rakyat.

Ketentuan kuorum dan jumlah minimal dukungan anggota DPR itu dimaksudkan agar pendapat DPR merupakan pendapat yang didukung oleh mayoritas anggota DPR.

(4) Mahkamah Konstitusi wajib memeriksa, mengadili, dan memutus dengan seadil-adilnya terhadap pendapat Dewan Perwakilan Rakyat tersebut paling lama sembilan puluh hari setelah permintaan Dewan Perwakilan Rakyat itu diterima oleh Mahkamah Konstitusi. 
Adapun jangka waktu yang disebut secara tegas dalam ketentuan Pasal 7B ayat (4) dimaksudkan untuk memberikan kepastian waktu sekaligus batas waktu (deadline) kepada MK. Ketentuan itu dimaksudkan untuk menghindarkan berlarutlarutnya proses pember-hentian Presiden dan/atau Wakil Presiden dalam masa jabatannya yang akan dapat meningkatkan ketegangan situasi politik nasional.

(5) Apabila Mahkamah Konstitusi memutuskan bahwa Presiden dan/atau Wakil Presiden terbukti melaku-kan pelanggaran hukum berupa pengkhianatan terhadap negara, korupsi, penyuapan, tindak pidana berat lainnya, atau perbuatan tercela; dan/atau terbukti bahwa Presiden dan/atau Wakil Presiden tidak lagi memenuhi syarat sebagai Presiden dan/atau Wakil Presiden, Dewan Perwakilan Rakyat menyelenggarakan sidang paripurna untuk meneruskan usul pemberhentian Presiden dan/atau Wakil Presiden kepada Majelis Permusyawaratan Rakyat.

Ketentuan tersebut diatas menunjukkan diterapkannya paham negara hukum sehingga hanya atas putusan MK, DPR dapat melanjutkan upaya pemberhentian Presiden dan/atau Wakil Presiden dalam masa jabatannya dengan cara menyelenggarakan sidang paripurna untuk meneruskan usul pemberhentian Presiden dan/atau Wakil Presiden kepada MPR.

(6) Majelis Permusyawaratan Rakyat wajib menyeleng-garakan sidang untuk memutuskan usul Dewan Perwakilan Rakyat tersebut paling lambat tiga puluh hari sejak Majelis Permusyawaratan Rakyat menerima usul tersebut.

(7) Keputusan Majelis Permusyawaratan Rakyat atas usul pemberhentian Presiden dan/atau Wakil Presiden harus diambil dalam rapat paripurna Majelis Permusyawaratan Rakyat yang dihadiri oleh sekurang-kurangnya 3/4 dari jumlah anggota dan disetujui oleh sekurang-kurangnya 2/3 dari jumlah anggota yang hadir, setelah Presiden dan/atau Wakil Presiden diberi kesempatan menyampaikan penjelasan dalam rapat paripurna Majelis Permusyawaratan Rakyat

Adanya ketentuan mengenai jangka waktu yang disebut secara tegas dalam ketentuan Pasal 7B ayat (6) dimaksudkan untuk memberikan kepastian waktu sekaligus batas waktu kepada MPR untuk menyelenggarakan sidang guna membahas usul pem-berhentian Presiden dan/atau Wakil Presiden oleh DPR. Ketentuan itu menghindarkan berlarut-larutnya proses pemberhentian Presiden dan/atau Wakil Presiden dalam masa jabatannya yang dapat meningkatkan ketegangan situasi politik nasional. Ketentuan kuorum sebanyak tiga perempat dari jumlah anggota MPR harus hadir dan disetujui oleh sekurang-kurangnya dua pertiga dari jumlah anggota MPR yang hadir dalam mengambil putusan terhadap usul DPR tersebut dimaksudkan untuk menghasilkan putusan yang didukung suara terbanyak. 
Rapat Paripurna MPR dapat negara, korupsi, penyuapan, tindak pidana memutuskan memberhentikan atau tidak berat lainnya, atau perbuatan tercela, diberhentikan Presiden dan/atau Wakil dan/atau tidak lagi memenuhi syarat sebagai Presiden dari jabatannya. Proses itu Presiden dan/atau Wakil Presiden. merupakan bagian dari ketentuan hukum Berdasarkan muatan berbagai konstitusi di yang diatur dalam Undang-Undang Dasar. banyak negara, pemberhentian Presiden Ketentuan Pasal 7B yang mengatur dan/atau Wakil Presiden dapat dilakukan pemberhentian Presiden dan/atau Wakil melalui proses dan keputusan politik Presiden dilakukan melalui tahapan yang (impeachment) atau melalui proses dan jelas dan tegas yang dilakukan tiga lembaga putusan hakim di pengadilan (forum negara, yaitu DPR, MK, dan MPR. previlegiatum). Pemberhentian melalui Walaupun dipilih oleh rakyat untuk impeachment dimaksudkan bahwa memimpin dan memegang kekuasaan pemberhentian Presiden dan/atau Wakil pemerintahan negara, sebagai manusia Presiden dilakukan dengan mekanisme dan Presiden dan/atau Wakil Presiden bisa saja syarat-syarat tertentu oleh lembaga melakukan kesalahan atau pelanggaran perwakilan rakyat, sedangkan pemberhentian hukum yang merusak sendi-sendi hidup melalui forum previlegiatum dimaksudkan bernegara dan mencederai hukum. Oleh bahwa pemberhentian Presiden dan/atau sebab itu, Presiden dan/atau Wakil Presiden Wakil Presiden melalui proses hukum dan bisa diberhentikan dalam masa putusan pengadilan.

jabatannya dengan alasan tertentu yang Berdasarkan Undang-Undang Dasar disebutkan secara limitatif di dalam Undang- Negara Republik Indonesia Tahun 1945, Undang Dasar Negara Republik Indonesia pemberhentian Presiden dan/atau Wakil Tahun 1945, yakni melalui proses politik (dengan adanya pendapat DPR dan keputusan pemberhentian MPR) dan melalui proses hukum (dengan cara Mahkamah Konstitusi memeriksa, mengadili, dan memutus pendapat DPR).

Perbuatan pelanggaran hukum yang secara limitatif dijadikan alasan untuk Presiden dapat dilakukan dengan proses impeachment oleh MPR jika proses hukum (forum previlegiatum) telah ditempuh melalui Mahkamah Konstitusi, yang sebelumnya harus didahului dengan pernyataan pendapat oleh DPR bahwa Presiden dan/atau Wakil Presiden telah melakukan pelanggaran hukum. Dengan memberhentikan Presiden dan/atau Wakil demikian, proses pemberhentian Presiden Presiden sebagaimana dimuat dalam pasal 7B dan/atau Wakil Presiden dalam masa ayat (1) adalah pengkhianatan terhadap jabatannya haruslah melalui tiga tahap. 
Pertama, pernyataan pendapat dari DPR bahwa Presiden dan/atau Wakil Presiden telah melakukan pelanggaran hukum sebagaimana diatur dalam pasal 7B ayat (1) Undang-Undang Dasar 1945. Kedua, adanya putusan Mahkamah Konstitusi bahwa pendapat DPR tersebut terbukti benar. Ketiga, pemberhentian oleh MPR jika MPR berketetapan bahwa pelanggaran yang dilakukan oleh Presiden dan/atau Wakil Presiden itu layak dijatuhi hukuman pemberhentian. Jadi, MPR tidak harus memberhentikan Presiden dan/atau Wakil Presiden meskipun putusan Mahkamah Konstitusi membenarkan pendapat DPR bahwa Presiden dan/atau Wakil Presiden telah melakukan pelanggaran hukum tertentu menurut konstitusi.

Tahapan-tahapan tersebut membuktikan bahwa dalam memberhentikan Presiden dan/atau Wakil Presiden yang masih dalam jabatannya, Undang-Undang Dasar Negara Republik Indonesia Tahun 1945 berpijak pada paham negara demokrasi seperti diatur dalam Pasal 1 ayat (2) dan berpijak pada paham negara hukum seperti diatur dalam pasal 1 ayat (3). Penerapan paham demokrasi dilakukan melalui pernyataan pendapat lebih dahulu oleh DPR dan pemberhentian oleh MPR, yang merupakan lembaga perwakilan dengan fungsi yang berbeda. Penerapan paham negara hukum dilakukan melalui forum previlegiatum, yakni dengan pemeriksaan, pengadilan, dan putusan oleh Mahkamah Konstitusi sebagai pemegang kekuasaan kehakiman sebelum MPR benar-benar memberhentikan Presiden dan/atau Wakil Presiden. Di sinilah terletak perpaduan penerapan antara paham demokrasi dan paham negara hukum.

Kembali pada pokok permasalahan yaitu masalah Hak Angket, dimana perihal tersebut telah diamanatkan oleh Pasal 7B (2), dapat dilihat bahwa pendapat DPR tentang dugaan pelanggaran hukum oleh Presiden dan/atau Wakil Presiden itu dalam rangka pelaksanaan fungsi pengawasan DPR. Fungsi pengawasan DPR untuk mengungkap pelanggaran hukum oleh Presiden dan/atau Wakil Presiden adalah hak angket. Penggunaan hak angket DPR terhadap Presiden memang bisa mengarah pada pemberhentian Presiden sebagaimana diatur dalam pasal 7A dan 7B perubahan ketiga UUD 1945. Harus diakui bahwa ketentuan pasal 7A dan 7B UUD 1945 ini merupakan hasil perkawinan dua konsep yang berbeda, yaitu konsep impeachment model amerika serikat disatu pihak, sementara keberadaan Mahkamah Konstitusi ditemukan di Perancis (The Constitutional Council) dan Jerman (The Constitutional Court). ${ }^{11}$ Berdasarkan pasal 7B tersebut proses impeachment terhadap Presiden dan/atau Wakil Presiden akan memerlukan waktu yang cukup

\footnotetext{
11 Rosjidi, Op.Cit, hlm.139
} 
panjang. ${ }^{12}$ Mengingat jabatan Presiden dan Wakil Presiden merupakan jabatan kenegaraan yang sangat penting, maka sebaiknya putusan terhadap dugaan pelanggaran oleh Presiden dan/atau Wakil Presiden dapat sesegera mungkin dituntaskan. ${ }^{13}$

Pada akhirnya harus disadari secara bersama-sama bahwa problematika hak angket merupakan problematika serius untuk saat ini dalam ketatanegaraan kita, terlebih ketika sistem kepartaian masih menggunakan sistem multipartai. Meskipun upaya impeachment melalui penggunaan hak angket tidak mudah tetapi dengan adanya sistem multipartai yang berakibat pada tidak adanya kekuatan politik mayoritas di DPR, maka Presiden dan/atau Wakil Presiden lebih rawan untuk dijadikan sasaran oleh tembak DPR ketika ada kebijakan Presiden dan/atau Wakil Presiden dianggap salah dan merugikan rakyat. Hak angket merupakan salah satu hak DPR secara fungsional yang memang sangat diperlukan, masalah terbesar yang kita hadapi adalah bahwa pada kenyatannya masih sangat banyak sekali oknum-oknum yang berkecimpung di DPR masih labil, tidak amanah dan yang pasti memiliki jiwa korup yang kuat. Sehingga orientasi dan mindset mereka tidak lagi menjiwai yang sebenarnya harus dijiwai yaitu suara rakyat.

\footnotetext{
12 Ibid

${ }^{13}$ Ibid
}

\section{Penutup}

Dari uraian diatas maka penulis dapat menarik beberapa kesimpulan yakni posisi hak angket DPR pada masa pra perubahan UUD 1945 tidak diatur. Sehingga pengarahan pada upaya pemberhentian Presiden dan/atau Wakil presiden (impiechment) oleh DPR melalui hak angket, tidak bisa dilakukan. Posisi hak angket DPR pada masa pasca perubahan UUD 1945 tepatnya pada perubahan ketiga sangatlah jelas diakomodir dalam UUD 1945, yaitu dalam Pasal 7B (2) UUD 1945. Dengan kekuatan dan kejelasan seperti itu sehingga bisa saja digunakan DPR untuk mengarahkan pada upaya pemberhentian Presiden dan/atau Wakil presiden (impiechment). Konsep check and balances lagi-lagi merupakan kiblat nyata yang harus benar-benar dipatuhi oleh sistem ketatanegaraan Indonesia. Masingmasing lembaga negara dengan tupoksi yang semestinya menjalankan tugas secraa ideal sesuai dengan konsep check and balances, berjalan dan bertindak. Jangan sampai melebihi tupoksi, sehingga menjadi berat dan merusak tatanan. Terkait pada penguatan fungsi pengawasan DPR, khususnya perihal hak angket, maka langkah bijak yang mungkin bisa menjadi masukan adalah dengan melakukan tatanan ulang pada jumlah partai politik. Penyederhanaan jumlah partai politik akan sangat membantu permasalahan ini. Sehingga Presiden dan/atau Wakil 
Presiden bisa menjalankan amanah yang dipegangnya tanpa harus memikirkan koalisi, tanpa harus merasa tertekan dengan serangan-serangan para anti-pati, serta juga mampu menghilangkan praktik bargaining $^{14}$ antara dirinya dengan partai politik.

\section{Daftar Pustaka}

\section{C.F Strong. 2012.Konstitusi-Konstitusi Politik-Politik Modern, Studi Perbandingan Sejarah dan Bentuk, Cetakan Ketujuh, Bandung : Nusa Media}

Dahlan Thaib et. al. (2004). Teori dan Hukum Konstitusi . Jakarta: Rajawali Press

Hotma P Sibuea. 2010. Asas Negara Hukum, Peraturan Kebijakan dan Asas-Asas umum Pemerintahan yang Baik. Jakarta : Erlangga

Jimly Asshidiqie. 2012. Pengantar Ilmu Hukum Tata Negara Jilid II. cetakan keempat. Jakarta : Penerbit Konstitusi Pers

Miriam Budiarjo. 1995.Dasar-Dasar Ilmu Politik, Jakarta : PT Gramedia Pustaka Utama

Moh Mahfud MD. 2000. Dasar dan Struktur Ketatanegaraan Indonesia. Rineka Cipta

Muhammad Yamin. 1971. Naskah Persiapan Undang-Undang Dasar 1945. Jakarta: Siguntang

\footnotetext{
${ }^{14}$ Tawar menawar yang beresensikan politik, sehingga memungkinkan munculnya keputusan yang tidak berpihak kepada rakyat. Karena ego sentris masingmasing lembaga terkait, memiliki tujuan dan pencapaian masing-masing. Kepentingan dan kebutuhan rakyat menjadi sangat ringan dalam perumusannya.
}

Ni'matul Huda. 2005. Hukum Tata Negara Indonesia. Depok : PT Raja Grafindo Persada

Rosjidi Ranggawidjaja. 2012. UndangUndang Dasar 1945 : diubah atau diganti ? Bandung : Universitas Padajdjaran

Sri Soematri. (2006). Prosedur dan Sistem Perubahan Konstitusi. Bandung Alumni

Undang-Undang Dasar Negara Republik Indonesia Tahun 1945 beserta perubahannya dalam satu naskah

Ketetapan Majelis Permusyawaratan Rakyat No.III/MPR/1978 